\title{
Punctate Palmoplantar Keratoderma
}

\section{Queratodermia Palmoplantar Punctate}

Susana Cláudia Teixeira ${ }^{1 *}$, André Coelho Almeida1 ${ }^{1}$ Joana Carvalho¹, Paulo Morais²

*Corresponding Author/Autor Correspondente:

Susana Cláudia Teixeira [snteixeira@chtmad.min-saude.pt] Centro Hospitalar de Trás-os-Montes e Alto Douro, Avenida Noruega, 5000-508 Vila Real, Portugal ORCID iD: 0000-0001-5827-909X

KEYWORDS: Child; Keratoderma, Palmoplantar/diagnosis; Keratoderma, Palmoplantar/genetics; Keratoderma, Palmoplantar/therapy

PALAVRAS-CHAVE: Criança; Queratodermia Palmoplantar/diagnóstico; Queratodermia Palmoplantar/genética; Queratodermia Palmoplantar/tratamento

A 5-year-old caucasian boy, born of non-consanguineous parents, was referred to the dermatology department due to palmar hiperlinearity and multiple 2-3 mm hyperkeratotic circular lesions in the soles (Fig. 1). The remaining physical examination was unremarkable. There was a family history of palmoplantar hyperkeratosis in the mother and maternal grandfather. To spare the child, a punch skin biopsy was taken from his mother. Pathology revealed an epidermis with irregular acanthosis and orthokeratotic hyperkeratosis, without other morphologic alterations (Fig. 2). Clinical aspect of the lesions associated with a positive family history and histologic findings allowed the diagnosis of punctate palmoplantar keratoderma. Satisfactory results were achieved with urea $20 \%$ cream and emollient applied to the soles.

Palmoplantar keratodermas are a heterogeneous group of hereditary or acquired diseases, characterized by an excessive epidermal thickening of palmoplantar surfaces. ${ }^{1-5}$ One of its rare hereditary forms is punctate palmoplantar keratoderma (Brauer-Buschke-Fischer syndrome), that follows a pattern of autosomal dominant inheritance with variable penetrance, and usually 


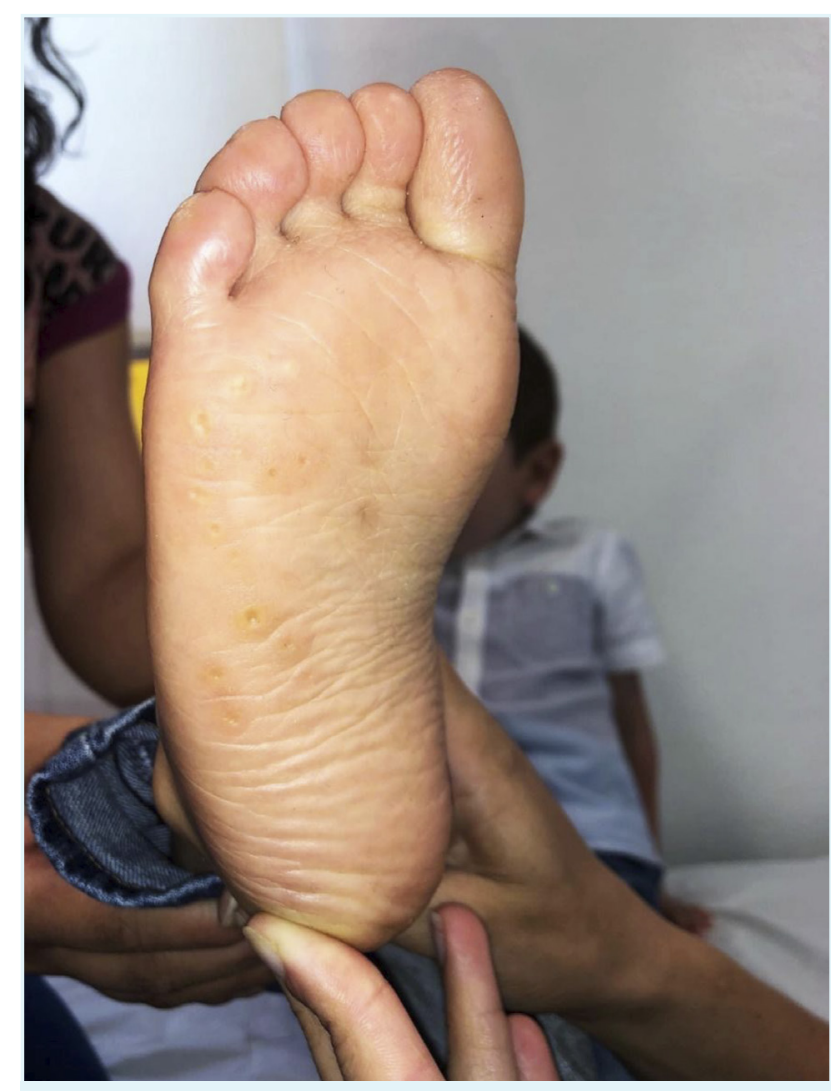

FIGURA 1. Hyperkeratotic circular lesions of 2-3 mm in diameter in the soles.

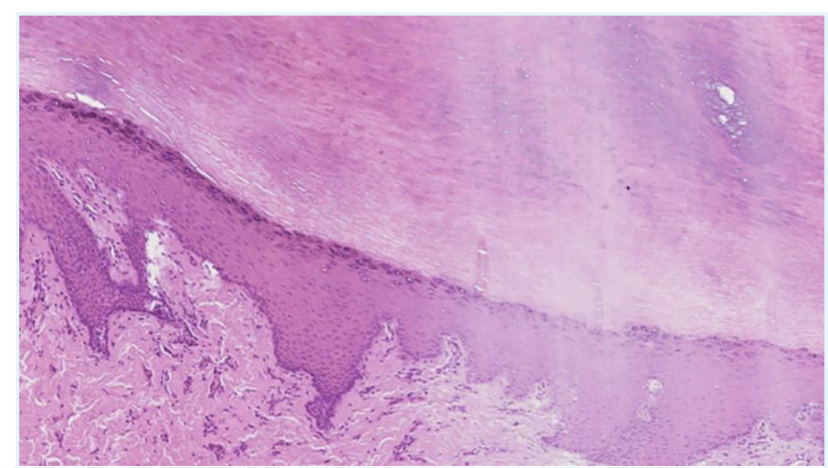

FIGURA 2. Histological cut of the sole skin of the mother reveals epidermis with irregular acanthosis and orthokeratotic hyperkeratosis (hematoxylin-eosin, 20X).

appears in late childhood to adulhood. ${ }^{3}$ In our case the age of presentation was much earlier, which is uncommon. This genodermatosis, although benign, tends to suffer clinical worsening over time, ${ }^{3}$ and may be associated with the development of neoplasms (pancreas, colon, breast, kidney and lymphoma).,2,4 There is no efficient treatment, although some improvement may be achieved with the use of emollients and topical keratolytics. Other treatments such as psoralen plus ultraviolet A (PUVA), systemic or topical retinoids or liquid nitrogen have also been used, with limited success. ${ }^{4}$

\section{RESPONSABILIDADES ÉTICAS}

CONFLITOS DE INTERESSE: Os autores declaram a inexistência de conflitos de interesse na realização do presente trabalho.

FONTES DE FINANCIAMENTO: Não existiram fontes externas de financiamento para a realização deste artigo.

CONFIDENCIALIDADE DOS DADOS: Os autores declaram ter seguido os protocolos da sua instituição acerca da publicação dos dados de doentes.

CONSENTIMENTO: Consentimento do doente para publicação obtido.

PROVENIÊNCIA E REVISÃO POR PARES: Não comissionado; revisão externa por pares.

\section{ETHICAL DISCLOSURES}

CONFLICTS OF INTEREST: The authors have no conflicts of interest to declare.

FINANCING SUPPORT: This work has not received any contribution, grant or scholarship.

CONFIDENTIALITY OF DATA: The authors declare that they have followed the protocols of their work center on the publication of data from patients.

PATIENT CONSENT: Consent for publication was obtained.

PROVENANCE AND PEER REVIEW: Not commissioned; externally peer reviewed.

\section{REFERENCES}

1. Bjorn R, Thomas BR, Edel A, O'Toole EA. Diagnosis and Management of Inherited Palmoplantar Keratodermas. Acta Derm Venereol. 2020; 100: adv00094:168-76. doi: 10.2340/00015555-3430.

2. Bukhari R, Alhawsawib W, Radin AA, Jan HD, Al Hawsawi K, Al Ahmadi M. Punctate Palmoplantar Keratoderma: A Case Report of Type 1 (Buschke-Fischer-Brauer Disease). Case Rep Dermatol. 2019;11:292-6. doi: 10.1159/000503337.

3. Guerra L, Castori M, Didona B, Castiglia D, Zambruno G. Hereditary palmoplantar keratodermas. Part I. Non-syndromic palmoplantar keratodermas: classification, clinical and genetic features. J Eur Acad Dermatol Venereol. 2018;32:704-19. doi: 10.1111/jdv.14902.

4. Sakiyama T, Kubo A. Hereditary palmoplantar keratoderma "clinical and genetic differential diagnosis". J Dermatol. 2016;43:264-74. doi: 10.1111/1346-8138.13219.

5. Monteiro AF, Rato M, Tavares E. Multiple bilateral hyperkeratotic palmoplantar papules. Eur J Dermatol. 2019;29:242-3. doi: 10.1684/ejd.2019.3565. 